\title{
Pharmacological Screening of Substituted Benzimidazole Derivatives
}

\author{
Poushali Saha, Shejuti Rahman Brishty and S. M. Abdur Rahman
}

Department of Clinical Pharmacy and Pharmacology, Faculty of Pharmacy, University of Dhaka, Dhaka-1000, Bangladesh

(Received: March 03, 2021, 2020; Accepted: May 26, 2021; Published (web): June 20, 2021)

\begin{abstract}
In the present study some substituted benzimidazole derivatives were screened for several biological activities. The synthesized compounds were subjected to evaluation of central analgesic, anti-inflammatory, cytotoxicity, antimicrobial and antioxidant activities by radiant heat induced tail flicking, carrageenan induced rat paw edema inhibition, brine shrimp lethality bioassay, disc diffusion and DPPH free radical scavenging methods, respectively. Compounds $\mathbf{2 a}, \mathbf{2 c}$ and $\mathbf{2 d}$ elongated the tail flicking time by 58.07-, 51.59- and 76.65\%, respectively (p $<0.001)$ at $50 \mathrm{mg} / \mathrm{kg}$ body weight dose compared to the standard morphine $(87.17 \%)$. Compounds $\mathbf{2 b}, \mathbf{2 c}$ and $2 \mathrm{~d}$ showed prominent anti-inflammatory activity at $100 \mathrm{mg} / \mathrm{kg}$ body weight dose (\% of paw edema inhibition $81.75 \%$, $79.09 \%$ and $86.69 \%$, respectively) compared to the standard aceclofenac (87.83\%). Among the synthesized benzimidazole derivatives, compounds $\mathbf{1 a}, \mathbf{1 b}, \mathbf{1 c}, \mathbf{2 a}$ and $\mathbf{2 d}$ exhibited potent cytotoxicity with the $\mathrm{IC}_{50}$ values of 5.47-, 11.92-, 4.55-, 7.63- and $7.94 \mu \mathrm{g} / \mathrm{ml}$, respectively. In addition, compounds $\mathbf{1 c}$ and $2 \mathbf{2 d}$ displayed mild to moderate zone of inhibition $(\mathbf{8 - 1 2} \mathbf{~ m m})$. On the other hand, $1 \mathbf{a}$ and $\mathbf{1 b}$ showed very mild antioxidant activity with $\mathrm{IC}_{50}$ values of $12.25 \times 10^{3} \mu \mathrm{g} / \mathrm{ml}$ and $87.33 \times 10^{3} \mu \mathrm{g} / \mathrm{ml}$. Among all the derivatives, $2 \mathbf{c}, \mathbf{2 d}$ and $\mathbf{1 c}$ can be potential candidates for designing new analgesic, anti-inflammatory and anti-cancer agents in future.
\end{abstract}

Key words: Benzimidazole, Central analgesic, Anti-inflammatory, Cytotoxicity, $\mathrm{IC}_{50}$, Antimicrobial

\section{INTRODUCTION}

Heterocyclic compounds possess outstanding implications in medicinal chemistry and new drug development because of their multifarious pharmacological actions. In recent decades, several heterocycles have been explored as targets for designing new drugs and benzimidazole has been one of the most significant heterocyclic moieties because of its broad spectrum of biological activities. ${ }^{1}$ Benzimidazole is a fusion of benzene and five membered imidazole ring. Its resemblance with naturally occurring nucleotides makes it a privileged structure to interact with several macromolecules like proteins, receptors and enzymes which establishes it

Correspondence to: S. M. Abdur Rahman Tel.: +88(02)9661920-73, Ext. 8166 (Office); +8801732477343 (Mobile);

Email:smarahman@du.ac.bd

Dhaka Univ. J. Pharm. Sci. 20(1): 95-102, 2021 (June)

DOI: https://doi.org/10.3329/dujps.v20i1.54037 as a potential candidate to design several drug molecules available in market. ${ }^{2}$ Numerous substituted benzimidazoles exhibit different biological activities like analgesic, e.g. etonitazene ${ }^{3}$; anti-inflammatory, e.g. emorfazone $4^{4}$; antimicrobial and antibacterial ${ }^{5}$; antiviral, e.g. maribavir ${ }^{6}$; fungicidal, e.g. benomyl ${ }^{7}$; anthelmintic, e.g. albendazole ${ }^{8}$; anti-cancer, e.g. veliparib $^{9}$; antihistaminic, e.g. astemizole $^{10}$; anticoagulant, e.g. dabigatran ${ }^{11}$; phosphodiesterase inhibitor, e.g. adibenden ${ }^{9}$; antihypertensive, e.g. candesartan $^{12}$; anti-emetic, e.g. ramosetron ${ }^{13}$, proton pump inhibitors, e.g. omeprazole ${ }^{14}$ and antidiarrheal, e.g. rifaximin ${ }^{15}$.

Evidently, the structural optimization of benzimidazole ring has emanated numerous potent commercially available therapeutic agents which instigated us to synthesize some benzimidazole analogs using a simple procedure and screen them for several pharmacological activities. In our previous 
reports, we have reported the synthetic pathway and peripheral analgesic and antidiarrheal activities of some disubstituted benzimidazole derivatives. ${ }^{16} \mathrm{We}$ have also reported the peripheral analgesic and antioxidant activities of some different benzimidazole derivatives with their synthetic pathway. ${ }^{17}$ In continuation of our ongoing research work on benzimidazoles $^{16-18}$, our present study aims at the evaluation of central analgesic, anti-inflammatory, cytotoxicity, antimicrobial and antioxidant activities of some 2-substituted benzimidazole derivatives with different substituents in various positions of the benzimidazole ring.

\section{MATERIALS AND METHODS}

Chemistry. Condensation of $o$-Phenylenediamine and 4-chloro-o-phenylenediamine with benzaldehyde and 4-chlorobenzaldehyde in the presence of ammonium chloride catalyst and chloroform solvent produced several monosubstituted and disubstituted benzimidazole derivatives which had been characterized as below (Figure 1). ${ }^{16}$

Chemicals and reagents. DMSO, sodium chloride, DPPH, ascorbic acid were obtained from Sigma Aldrich, USA.

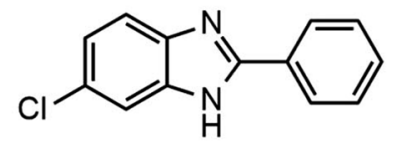

$1 \mathrm{c}$

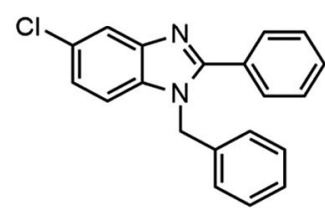

2c

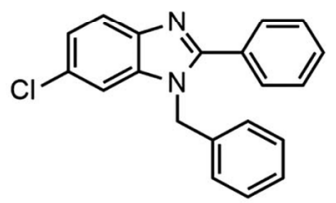

2d

Figure 1. Synthesized mono and disubstituted benzimidazole derivatives; 1a: 2-Phenyl-1- $H$-benzimidazole; 2a: 1-Benzyl-2-phenyl-1- $H$ benzimidazole; 1b: 2-(4-Chlorophenyl)-1- $H$-benzimidazole; 2b: 1-(4-Chlorobenzyl)-2-(4-chlorophenyl)-1- $H$-benzimidazole; 1c: 2Phenyl-6-chloro-1- $H$-benzimidazole; 2c: 1-Benzyl-2-phenyl-5-chloro-1- $H$-benzimidazole; 2d: 1-Benzyl-2-phenyl-6-chloro-1- $H$ benzimidazole.

Pharmacological screenings. All the synthesized substituted benzimidazole derivatives mentioned above were subjected to assays to evaluate in vivo central analgesic and anti-inflammatory activities by calculating the animal responses towards thermal and chemical inducements. In vitro brine shrimp lethality, antimicrobial and antioxidant activities were also screened for these compounds.

Experimental animal. Swiss-albino mice (Mus musculus) weighing 25-30 grams of either sex, aged 4-5 weeks and Wister rats (Rattus norvigicus) of either sex, weighed 100-150 gm obtained from the Animal House of Jahangirnagar University were used for evaluating central analgesic and anti- inflammatory activities respectively. They were housed separately in standard polypropylene cages under controlled room temperature $\left(24 \pm 2^{\circ} \mathrm{C}\right.$; relative humidity $60-70 \%, 12 \mathrm{~h}$ light and dark cycle $^{19}$ ) in the Animal House of the Institute of Nutrition and Food Science, University of Dhaka. The mice were fed with rodent food and water formulated by The International Centre for Diarrheal Diseases and Research, Bangladesh (iccddr,b). Only water was fed to the animals 12 hours prior to the experiment. The ethics of using experimental animals were followed carefully during the experiments.

Evaluation of central analgesic activity: In vivo central analgesic activity was evaluated by the 
radiant heat tail flick method using Swiss-albino mice (Mus musculus). ${ }^{20-22}$

Experimental design. Eighty experimental mice were randomly selected and divided into 16 groups each consisting of 5 mice receiving one particular treatment i.e. control, standard (morphine $2 \mathrm{mg} / \mathrm{kg}$ b.w.), lower dose and upper dose (25- and 50- $\mathrm{mg} / \mathrm{kg}$ body weight). The doses of the test samples, standard and control materials were adjusted according to the weight of each mouse. A constant heat stress $\left(55 \pm 2^{\circ}\right.$ C) was applied to mice tail $(2.5 \mathrm{~cm}$ measured from the root of the tail and the distance between the heat source and the tail skin was $1.5 \mathrm{~cm}$ ) as pain stimulus. When the stimulus exceeds the threshold, mice show a quick withdrawal of their tails. The time taken by a mouse to withdraw its tail is called tail flicking time. Test samples and control were orally administered to the mice at zero hour using a feeding needle and to ensure proper absorption 30 minutes interval was given. Then morphine solution was administered subcutaneously to the mice. Tail flicking time was measured after 30-, 60- and 90-minutes by analgesiometer (Medicraft, India). The percentage elongation of tail flicking time was compared with the control group and was considered as an index of central analgesia and calculated using the following formula:

$$
\% \text { time elongation }=\frac{\mathrm{Tt}-\mathrm{Tc}}{\mathrm{Tc}} \times 100
$$

Where $\mathrm{Tt}$ is the average time of tail flicking of test groups and $\mathrm{Tc}$ is the average time of tail flicking of control group.

Evaluation of anti-inflammatory activity. Carrageenan-induced rat hind paw edema was used as the animal model of acute inflammation to evaluate in vivo anti-inflammatory activity of the synthesized benzimidazole derivatives. ${ }^{23,24}$

Experimental design. Forty-five experimental rats (Rattus norvigicus) were selected randomly and divided into 9 groups each consisting of 5 rats receiving one particular treatment i.e. control $(0.9 \%$ saline water), standard (Aceclofenac) and synthesized compounds at the dose of $100 \mathrm{mg} / \mathrm{kg}$ body weight. The doses of the test samples, standard and control materials were adjusted according to the weight of each rat. Administration of carrageenan in the subplantar region of rat's hind paw produced edema in situ due to localized inflammation. Test materials and standard anti-inflammatory drug were administered to the experimental rats at appropriate doses about one hour prior to the administration of carrageenan solution. The rat's paw volumes were measured by a plethysmometer (37140, Ugo Basile, Italy) at $1^{\text {st }}, 2^{\text {nd }}$, $3^{\text {rd }}$ and $4^{\text {th }}$ hours after the administration of the standard drug and test sample. The average percentage of increase in paw volume with time was calculated and compared to the control group. The percent inhibition of edema formation was calculated using the formula-

$$
\% \text { inhibition }=\frac{\mathrm{Vc}-\mathrm{Vt}}{\mathrm{Vc}} \times 100
$$

Where, Vc and Vt represent the average paw edema volume of control and treated animals groups respectively.

Brine shrimp lethality bioassay. The cytotoxicity assay was performed on brine shrimp nauplii (Artemia nauplii) using Meyer method ${ }^{25}$ with minor modifications. Standard (Vincristine sulphate) and synthesized samples of different concentrations (400-, 200-, 100-, 50-, 25 -, 12.5-, 6.25-, 3.125-, $1.563-$ and $0.781-\mu \mathrm{g} / \mathrm{ml}$ ) were prepared by serial dilution using DMSO as solvent and taken in the premarked test tubes, each containing 10 nauplii and 5 $\mathrm{ml}$ of simulated sea water. ${ }^{26}$ A negative control (100 $\mu \mathrm{L}$ DMSO) was also performed using the same manner. Then the test tubes were kept in light for 24 hours and the survivors were counted after 24 hours. These data were processed to estimate $\mathrm{LC}_{50}$ values with $95 \%$ confidence intervals for statistically significant comparisons of cytotoxicity of the benzimidazole derivatives.

Antimicrobial assay. Disc diffusion method was used to evaluate antimicrobial activity of the synthesized compounds. ${ }^{27,28} \mathrm{~A}$ microbial culture (sixteen strains of gram positive, gram negative bacteria and fungi adjusted to 0.5 McFarland standard), was used to lawn in nutrient agar plates evenly and was subjected to the sensitivity test after 15 minutes of drying. The discs $(6 \mathrm{~mm})$ impregnated with standard (Ciprofloxacin $5 \mu \mathrm{g} / \mathrm{disc}$ ), test samples 
(400 $\mu \mathrm{g} / \mathrm{disc})$ and control (blank disc) were placed on the agar media. These plates were kept at low temperature $\left(4^{\circ} \mathrm{C}\right)$ for 24 hours to allow maximum diffusion of the materials and then inverted and incubated at $37^{\circ} \mathrm{C}$ for 24 hours for optimal growth of the organisms. After incubation, the plates were examined for inhibition zone and measured using calipers.

Evaluation of antioxidant activity. In vitro antioxidant activity of the synthesized benzimidazole derivatives was screened using DPPH (2,2- diphenyl1-picrylhydrazyl) free radical assay. ${ }^{29}$ Methanolic solutions of ascorbic acid (standard) and the synthesized samples were prepared by serial dilution in ten different concentrations (0.977-, 1.953-, 3.906, 7.813-, 15.625-, 31.25-, 62.5-, 125-, 250- and 500$\mu \mathrm{g} / \mathrm{ml}$ ), mixed with $3.0 \mathrm{ml}$ of a DPPH methanol solution $(20 \mu \mathrm{g} / \mathrm{ml})$ and incubated for $30 \mathrm{~min}$ in a dark place at room temperature. After incubation, the absorbance was measured at $517 \mathrm{~nm}$ using UV-Vis Spectrophotometer against blank methanol. The inhibition of free radical DPPH in percent (I \%) was calculated using the following equation:

$$
(\mathrm{I} \%)=\left(1-\mathrm{A}_{\text {sample }} / \mathrm{A}_{\text {blank }}\right) \times 100
$$

Where $A_{\text {blank }}$ is the absorbance of control reaction and $\mathrm{A}_{\text {sample }}$ is the absorbance of sample reaction. The $\%$ inhibitions were plotted against concentrations of the samples and $\mathrm{IC}_{50}$ was calculated from the graph.

Statistical analysis. All the results of the tests were expressed as the mean \pm standard error of the mean (SEM) and the results were analyzed using the One Way Analysis of Variance (ANOVA) followed by Dunnett's test by using Graph Pad software. $\mathrm{P}<0.05$ was considered to be statistically significant.

\section{RESULTS AND DISCUSSION}

During evaluation of central analgesic activity, all the synthesized benzimidazole derivatives elongated the tail flicking time. Statistical analysis exhibited that compounds $\mathbf{2 a}, \mathbf{2 c}$ and $\mathbf{2 d}$ showed promising activity at $50 \mathrm{mg} / \mathrm{kg}$ body weight dose $(\%$ of elongation $58.07 \%, 51.59 \%$ and $76.65 \%$, respectively, $\mathrm{p}<0.001$ ) and other synthesized derivatives at both $25-$ and $50-\mathrm{mg} / \mathrm{kg}$ body weight doses exhibited mild to moderate activity. The results are shown in Table 1. The radiant heat induced tail flicking method is a well-established method to identify central analgesic activity from peripheral analgesic activity. The standard Morphine used in the study acts as an agonist of $\mathrm{Mu}$ opiate receptor (MOP) mainly, but also has some effects on delta opiate receptor (DOP) and kappa opiate receptor (KOP) and MOP receptor agonism is the major reason of causing analgesic activities. ${ }^{30}$ As the results of the test samples obtained from the tail flicking test are comparable to that of the standard morphine, there is a possibility that these compounds act by interfering with the opioid receptors in the synthesized compounds.

In the screening for anti-inflammatory activity, all the substituted benzimidazole derivatives inhibited the formation of rat paw edema compared to the control group. Statistical analysis $(p<0.001)$ showed that compounds $\mathbf{2 b}, \mathbf{2 c}$ and $\mathbf{2 d}$ showed prominent anti-inflammatory activity at a dose of $100 \mathrm{mg} / \mathrm{kg}$ body weight (\% of paw edema inhibition $81.75 \%$, $79.09 \%$ and $86.69 \%$, respectively) and the other derivatives showed moderate activities. The results have been shown in Table 2. A spectrum of benzimidazole derivatives are reported for their antiinflammatory activity due to their ability to act on various therapeutic targets such as cyclooxygenase (COX) enzyme, transient receptor potential vanilloid1 (TRPV-1) ion channels, cannabinoid receptors, bradykinin receptors, specific cytokines and 5-lipoxygenase activating protein (FLAP). ${ }^{31,32}$ Compared to the standard Aceclofenac, the synthesized benzimidazole derivatives showed moderate anti-inflammatory activity and so, the compounds can be potential candidates for design and development of new anti-inflammatory agents.

Brine shrimp lethality bioassay was performed as a preliminary phase of evaluating cytotoxic activity of the synthesized benzimidazole derivatives. Compounds 1a, 1b, 1c, 2a and 2d exhibited potent cytotoxic activity with the $\mathrm{IC}_{50}$ values of 5.47-, 11.92-, 4.55-, 7.63- and 7.94- $\mu \mathrm{g} / \mathrm{ml}$, respectively. 
However, compounds $\mathbf{2 b}$ and $\mathbf{2 c}$ showed moderate and weak cytotoxicity with $\mathrm{IC}_{50}$ values of 46.095 and $308.404-\mu \mathrm{g} / \mathrm{ml}$, respectively when compared to that of standard vincristine sulphate $\left(\mathrm{IC}_{50}=0.544\right.$ $\mu \mathrm{g} / \mathrm{ml})$. The results of the assay are summarized in Table 3. Like various benzimidazole drivatives ${ }^{33}$ and metal complexes of benzimidazoles ${ }^{34}$ our synthesized substituted benzimidazoles 1a, 1b, 1c, 2a and 2d have shown potent cytotoxicity in brine shrimp lethality bioassay. Hence, these compounds can be potential candidates for designing new anticancer molecules.

Table 1. In vivo central analgesic activity of the synthesized benzimidazole derivatives in mice.

\begin{tabular}{|c|c|c|c|c|c|c|c|c|}
\hline \multirow{2}{*}{$\begin{array}{l}\text { Sample } \\
\text { code }\end{array}$} & \multicolumn{4}{|c|}{ Average Tail Flicking Time } & \multicolumn{4}{|c|}{$\%$ Elongation } \\
\hline & $0 \mathrm{~min}$. & $30 \mathrm{~min}$. & $60 \mathrm{~min}$. & $90 \mathrm{~min}$. & $0 \mathrm{~min}$. & $30 \mathrm{~min}$. & $60 \mathrm{~min}$. & $90 \mathrm{~min}$. \\
\hline $\mathrm{CS}$ & $7.09 \pm 0.323$ & $8.18 \pm 0.401$ & $7.53 \pm 0.2145$ & $8.26 \pm 0.35$ & - & - & - & - \\
\hline $\mathrm{SS}_{\mathrm{M}}$ & $13.27 \pm 0.706^{* * *}$ & $14.29 \pm 0.55^{* * *}$ & $12.47 \pm 0.63^{* *}$ & $10.47 \pm 0.65^{* * *}$ & 87.17 & 74.69 & 65.58 & 26.76 \\
\hline $1 \mathrm{a}\left(\mathrm{d}_{1}\right)$ & $7.94 \pm 0.331 * *$ & $10.0 \pm 0.54$ & $8.91 \pm 0.563 * *$ & $9.68 \pm 0.519$ & 11.99 & 22.27 & 18.33 & 17.19 \\
\hline $1 \mathrm{a}\left(\mathrm{d}_{2}\right)$ & $8.94 \pm 0.526 * * *$ & $11.22 \pm 0.38 * * *$ & $9.87 \pm 0.416^{* *}$ & $10.07 \pm 0.97$ & 26.09 & 37.16 & 31.08 & 21.91 \\
\hline $2 \mathrm{a}\left(\mathrm{d}_{1}\right)$ & $7.84 \pm 0.391 * * *$ & $9.69 \pm 0.476^{* * *}$ & $9.75 \pm 0.241 * * *$ & $10.40 \pm 0.71 * * *$ & 10.57 & 18.46 & 29.48 & 25.91 \\
\hline $2 \mathrm{a}\left(\mathrm{d}_{2}\right)$ & $11.72 \pm 0.703^{* * *}$ & $12.93 \pm 0.39 * * *$ & $10.32 \pm 0.372 * * *$ & $9.61 \pm 0.35^{* *}$ & 65.30 & 58.07 & 37.11 & 16.34 \\
\hline $1 \mathrm{~b}\left(\mathrm{~d}_{1}\right)$ & $9.35 \pm 0.62 * *$ & $9.92 \pm 0.44$ & $10.79 \pm 0.341^{* * *}$ & $11.56 \pm 0.54 * * *$ & 31.88 & 21.27 & 43.29 & 39.95 \\
\hline $1 \mathrm{~b}\left(\mathrm{~d}_{2}\right)$ & $11.41 \pm 0.471 * * *$ & $13.17 \pm 0.65^{* * *}$ & $17.18 \pm 0.506^{* * *}$ & $11.59 \pm 0.48 * * *$ & 60.93 & 61.00 & 128.15 & 40.31 \\
\hline $2 \mathrm{~b}\left(\mathrm{~d}_{1}\right)$ & $10.07 \pm 0.51 * *$ & $18.81 \pm 0.55^{* * *}$ & $13.18 \pm 0.466^{* * *}$ & $13.44 \pm 0.94 * * *$ & 42.03 & 129.95 & 75.03 & 62.71 \\
\hline $2 \mathrm{~b}\left(\mathrm{~d}_{2}\right)$ & $11.87 \pm 0.557 * * *$ & $13.29 \pm 0.46^{* * *}$ & $14.72 \pm 0.279 * * *$ & $18.07 \pm 0.38 * * *$ & 67.42 & 62.47 & 95.49 & 118.77 \\
\hline $1 \mathrm{c}\left(\mathrm{d}_{1}\right)$ & $9.31 \pm 0.545^{* *}$ & $10.60 \pm 0.35^{*}$ & $12.43 \pm 0.595 * * *$ & $10.57 \pm 0.55^{* * *}$ & 31.31 & 29.58 & 65.07 & 27.97 \\
\hline $1 \mathrm{c}\left(\mathrm{d}_{2}\right)$ & $10.20 \pm 0.53^{*}$ & $11.15 \pm 0.562 * *$ & $11.56 \pm 0.451$ & $11.96 \pm 0.51^{*}$ & 43.87 & 36.30 & 53.52 & 44.79 \\
\hline $2 \mathrm{c}\left(\mathrm{d}_{1}\right)$ & $9.48 \pm 0.604 * * *$ & $11.47 \pm 0.361 * *$ & $17.99 \pm 0.523$ & $12.05 \pm 0.46^{*}$ & 33.85 & 40.22 & 138.91 & 45.88 \\
\hline $2 \mathrm{c}\left(\mathrm{d}_{2}\right)$ & $11.4 \pm 0.694 * * *$ & $12.40 \pm 0.24 * * *$ & $17.54 \pm 0.594 * * *$ & $16.89 \pm 1.15^{* * *}$ & 60.79 & 51.59 & 132.93 & 104.48 \\
\hline $2 \mathrm{~d}\left(\mathrm{~d}_{1}\right)$ & $8.70 \pm 0.77 * * *$ & $9.99 \pm 0.313 * * *$ & $10.13 \pm 0.56^{*}$ & $10.89 \pm 0.55^{* * *}$ & 22.71 & 21.52 & 34.53 & 31.84 \\
\hline $2 \mathrm{~d}\left(\mathrm{~d}_{2}\right)$ & $11.08 \pm 0.382 * * *$ & $12.29 \pm 0.76^{* * *}$ & $13.30 \pm 0.371 * *$ & $13.14 \pm 0.49 * * *$ & 56.28 & 50.24 & 76.65 & 59.08 \\
\hline
\end{tabular}

Each value represents the Mean \pm SEM $(\mathrm{n}=5), * * * \mathrm{p}<0.001, * * \mathrm{p}<0.01, * \mathrm{p}<0.05$ compared with control (one-way ANOVA followed by Dunnett's test); $\mathrm{CS}=$ Control sample; $\mathrm{SS}_{\mathrm{M}}=$ Standard sample (Morphine, $2 \mathrm{mg} / \mathrm{kg}$ b.w.); $\left(\mathrm{d}_{1}\right)=$ Lower dose $\left(25 \mathrm{mg} / \mathrm{kg}\right.$ b.w.); $\left(\mathrm{d}_{2}\right)=$ Higher dose (50 mg/kg b.w.).

Table 2. In vivo anti-inflammatory activity of the synthesized benzimidazole derivatives in rat model.

\begin{tabular}{|c|c|c|c|c|c|c|c|c|}
\hline \multirow{2}{*}{$\begin{array}{l}\text { Sample } \\
\text { code }\end{array}$} & \multicolumn{4}{|c|}{ Average Paw Volume } & \multicolumn{4}{|c|}{$\%$ Inhibition of Paw Edema } \\
\hline & $1^{\text {st }}$ hour & $2^{\text {nd }}$ hour & $3^{\text {rd }}$ hour & $4^{\text {th }}$ hour & $1^{\text {st }}$ hour & $\begin{array}{c}2^{\text {nd }} \\
\text { hour }\end{array}$ & $\begin{array}{c}3^{\text {rd }} \\
\text { hour }\end{array}$ & $\begin{array}{l}4^{\text {th }} \\
\text { hour }\end{array}$ \\
\hline $\mathrm{CS}$ & 0.772 & 0.804 & 0.822 & 0.86 & 0 & 0 & 0 & 0 \\
\hline $\mathrm{SS}_{\mathrm{A}}$ & $0.618 \pm 0.017 * * *$ & $0.584 \pm 0.015^{* * *}$ & $0.562 \pm 0.011^{* * *}$ & $0.514 \pm 0.013^{* * *}$ & 61.64 & 71.49 & 77.05 & 87.83 \\
\hline $1 \mathrm{a}$ & $0.99 \pm 0.025^{* *}$ & $0.946 \pm 0.023^{* * *}$ & $0.868 \pm 0.028$ & $0.846 \pm 0.028$ & 4.11 & 20 & 38.93 & 47.53 \\
\hline $2 \mathrm{a}$ & $0.866 \pm 0.032^{* * * *}$ & $0.826 \pm 0.041 * *$ & $0.76 \pm 0.03 * *$ & $0.732 \pm 0.032^{* * *}$ & 21.01 & 34.89 & 50.82 & 59.69 \\
\hline $1 b$ & $0.984 \pm 0.027$ & $0.928 \pm 0.036 * *$ & $0.856 \pm 0.035^{* * *}$ & $0.802 \pm 0.03$ & 5.48 & 23.83 & 41.39 & 55.89 \\
\hline $2 b$ & $0.816 \pm 0.031^{* *}$ & $0.78 \pm 0.035^{* *}$ & $0.738 \pm 0.031 * * *$ & $0.718 \pm 0.029 * *$ & 55.71 & 66.38 & 76.23 & 81.75 \\
\hline $1 \mathrm{c}$ & $0.898 \pm 0.03^{* *}$ & $0.832 \pm 0.028 * * *$ & $0.782 \pm 0.026^{* * *}$ & $0.758 \pm 0.039$ & 41.55 & 59.57 & 71.31 & 77.95 \\
\hline $2 \mathrm{c}$ & $0.716 \pm 0.018^{* * *}$ & $0.668 \pm 0.017^{* * *}$ & $0.612 \pm 0.008 * *$ & $0.572 \pm 0.01^{* *}$ & 42.01 & 56.17 & 69.26 & 79.09 \\
\hline $2 \mathrm{~d}$ & $0.75 \pm 0.023^{* *}$ & $0.71 \pm 0.025^{* * *}$ & $0.69 \pm 0.032 * *$ & $0.664 \pm 0.026^{* *}$ & 64.39 & 75.32 & 80.33 & 86.69 \\
\hline
\end{tabular}

Each value represents the mean $\pm \operatorname{SEM}(\mathrm{n}=5), * * * \mathrm{p}<0.001, * * \mathrm{p}<0.01,{ }^{*} \mathrm{p}<0.05$ compared with control (one-way ANOVA followed by Dunnett's test); $\mathrm{CS}=$ Control sample, $\mathrm{SS}_{\mathrm{A}}=$ Standard sample, Aceclofenac, dose $=100 \mathrm{mg} / \mathrm{kg}$ body weight. 
Table 3. Cytotoxicity of benzimidazole derivatives by brine shrimp lethality bioassay.

\begin{tabular}{|c|c|c|c|c|c|c|c|c|c|c|c|}
\hline \multirow[b]{2}{*}{ Sample } & \multicolumn{10}{|c|}{$\%$ Mortality } & \multirow{2}{*}{$\begin{array}{c}\mathrm{IC}_{50} \\
\text { value } \\
(\mu \mathrm{g} / \mathrm{ml})\end{array}$} \\
\hline & $\begin{array}{c}0.78125 \\
\mu \mathrm{g} / \mathrm{ml} \\
\end{array}$ & $\begin{array}{l}1.5625 \\
\mu \mathrm{g} / \mathrm{ml} \\
\end{array}$ & $\begin{array}{l}3.125 \\
\mu \mathrm{g} / \mathrm{ml}\end{array}$ & $\begin{array}{c}6.25 \\
\mu \mathrm{g} / \mathrm{ml} \\
\end{array}$ & $\begin{array}{c}12.5 \\
\mu \mathrm{g} / \mathrm{ml} \\
\end{array}$ & $\begin{array}{c}25 \\
\mu \mathrm{g} / \mathrm{ml} \\
\end{array}$ & $\begin{array}{c}50 \\
\mu \mathrm{g} / \mathrm{ml} \\
\end{array}$ & $\begin{array}{c}100 \\
\mu \mathrm{g} / \mathrm{ml}\end{array}$ & $\begin{array}{c}200 \\
\mu \mathrm{g} / \mathrm{ml}\end{array}$ & $\begin{array}{c}400 \\
\mu \mathrm{g} / \mathrm{ml}\end{array}$ & \\
\hline $\mathrm{SS}_{\mathrm{V}}$ & 20 & 30 & 40 & 50 & 60 & 80 & 90 & 100 & 100 & 100 & 0.544 \\
\hline $1 \mathrm{a}$ & 30 & 40 & 30 & 40 & 60 & 70 & 90 & 100 & 100 & 100 & 5.47 \\
\hline $2 a$ & 20 & 20 & 30 & 50 & 50 & 70 & 90 & 100 & 100 & 100 & 7.63 \\
\hline $1 b$ & 10 & 20 & 40 & 40 & 50 & 70 & 70 & 80 & 80 & 90 & 11.917 \\
\hline $2 b$ & 0 & 10 & 10 & 10 & 20 & 20 & 30 & 50 & 100 & 100 & 46.095 \\
\hline $1 \mathrm{c}$ & 10 & 30 & 40 & 50 & 80 & 100 & 100 & 100 & 100 & 100 & 4.55 \\
\hline $2 c$ & 0 & 10 & 10 & 20 & 30 & 20 & 30 & 30 & 40 & 70 & 308.404 \\
\hline $2 d$ & 10 & 20 & 20 & 30 & 70 & 90 & 100 & 100 & 100 & 100 & 7.94 \\
\hline
\end{tabular}

$\mathrm{SS}_{\mathrm{V}}=$ Standard sample (Vincristine sulphate)

Table 4. Antimicrobial activity of the synthesized benzimidazole derivatives.

\begin{tabular}{|c|c|c|c|c|c|c|c|c|}
\hline \multirow[t]{2}{*}{ Test organisms } & \multicolumn{8}{|c|}{ Zone of inhibition (mm) } \\
\hline & Ciprofloxacin & $1 \mathrm{a}$ & $2 \mathrm{a}$ & $1 \mathrm{~b}$ & $2 \mathrm{~b}$ & $1 \mathrm{c}$ & $2 \mathrm{c}$ & $2 \mathrm{~d}$ \\
\hline \multicolumn{9}{|l|}{ Gram Positive Bacteria } \\
\hline Bacillus cereus & 45 & - & - & - & - & 9 & - & 8 \\
\hline B. megaterium & 47 & - & - & - & - & 9 & - & 8 \\
\hline B. subtilis & 37 & - & - & - & - & 10 & - & 9 \\
\hline Sarcina lutea & 41 & - & - & - & - & 11 & - & 12 \\
\hline Staphylococcus aureus & 48 & - & - & - & - & 8 & - & 8 \\
\hline \multicolumn{9}{|l|}{ Gram Negative Bacteria } \\
\hline Escherichia coli & 43 & - & - & - & - & 12 & - & 8 \\
\hline Pseudomonas aeruginosa & 44 & - & - & - & - & 8 & - & 7 \\
\hline Salmonella paratyphi & 38 & - & - & - & - & 10 & - & 8 \\
\hline S. typhi & 48 & - & - & - & - & 9 & - & 8 \\
\hline Shigella boydii & 37 & - & - & - & - & 10 & - & 9 \\
\hline Sh. dysenteriae & 44 & - & - & - & - & 9 & - & 8 \\
\hline Vibrio mimicus & 42 & - & - & - & - & 9 & - & 7 \\
\hline V. parahaemolyticus & 40 & - & - & - & - & 10 & - & 8 \\
\hline \multicolumn{9}{|l|}{ Fungi } \\
\hline Aspergillus niger & 49 & - & - & - & - & 8 & - & - \\
\hline Candida albicans & 45 & - & - & - & - & 7 & - & - \\
\hline Saccharomyces cerevisiae & 37 & - & - & - & - & 12 & - & 10 \\
\hline
\end{tabular}

Table 5. Antioxidant activity of the synthesized benzimidazole derivatives by DPPH free radical scavenging assay.

\begin{tabular}{|c|c|c|c|c|c|c|c|c|c|c|c|}
\hline \multirow[t]{2}{*}{ Sample } & \multicolumn{10}{|c|}{ Inhibition of DPPH free radical at different concentrations (\%) } & \multirow{2}{*}{$\begin{array}{c}\text { IC }_{50} \text { value } \\
(\mu \mathrm{g} / \mathrm{ml})\end{array}$} \\
\hline & $\begin{array}{l}0.977 \\
\mu \mathrm{g} / \mathrm{ml}\end{array}$ & $\begin{array}{l}1.953 \\
\mu \mathrm{g} / \mathrm{ml}\end{array}$ & $\begin{array}{l}3.906 \\
\mu \mathrm{g} / \mathrm{ml}\end{array}$ & $\begin{array}{l}7.813 \\
\mu \mathrm{g} / \mathrm{ml}\end{array}$ & $\begin{array}{l}15.625 \\
\mu \mathrm{g} / \mathrm{ml}\end{array}$ & $\begin{array}{c}31.25 \mu \\
\mathrm{g} / \mathrm{ml}\end{array}$ & $\begin{array}{c}62.5 \\
\mu \mathrm{g} / \mathrm{ml}\end{array}$ & $\begin{array}{c}125 \\
\mu \mathrm{g} / \mathrm{ml}\end{array}$ & $\begin{array}{c}250 \\
\mu \mathrm{g} / \mathrm{ml}\end{array}$ & $\begin{array}{c}500 \\
\mu \mathrm{g} / \mathrm{ml}\end{array}$ & \\
\hline SS & 30.05 & 35.79 & 50.55 & 78.96 & 91.67 & 93.58 & 96.72 & 97.95 & 98.36 & 98.36 & 2.19 \\
\hline $1 \mathrm{a}$ & 32.10 & 32.51 & 34.02 & 34.15 & 34.83 & 40.03 & 40.43 & 40.57 & 41.80 & 43.85 & $12.25 \times 10^{3}$ \\
\hline $2 a$ & 31.56 & 32.79 & 33.06 & 33.47 & 33.61 & 36.20 & 37.84 & 38.79 & 39.48 & 41.12 & $212.02 \times 10^{3}$ \\
\hline $1 b$ & 25.82 & 26.09 & 25.96 & 27.73 & 28.14 & 28.28 & 30.19 & 34.70 & 38.66 & 40.16 & $87.33 \times 10^{3}$ \\
\hline $2 b$ & 27.60 & 27.87 & 30.60 & 30.87 & 31.01 & 32.10 & 35.66 & 36.61 & 36.75 & 38.12 & $385.66 \times 10^{3}$ \\
\hline $1 \mathrm{c}$ & 19.13 & 19.81 & 20.63 & 23.63 & 24.73 & 25.14 & 25.14 & 25.27 & 26.09 & 28.42 & $4.64 \times 10^{9}$ \\
\hline $2 \mathrm{c}$ & 15.44 & 20.22 & 21.18 & 21.86 & 22.40 & 22.68 & 23.91 & 24.45 & 25.68 & 27.32 & $2.98 \times 10^{9}$ \\
\hline $2 d$ & 19.54 & 20.36 & 23.09 & 23.09 & 23.91 & 23.91 & 25.82 & 26.22 & 27.60 & 32.92 & $6.37 \times 10^{7}$ \\
\hline
\end{tabular}

SS $=$ Standard Sample (Ascorbic Acid). 
In antimicrobial assay, compounds $\mathbf{1 c}$ and $\mathbf{2 d}$ showed mild to moderate antimicrobial activity against $\mathrm{gm}+\mathrm{ve}$, gm -ve bacteria and fungi with zone of inhibition ranging from $8-12 \mathrm{~mm}$ diameter compared to standard ciprofloxacin disc (37-49 mm). Other test compounds did not show any significant antimicrobial activity against the microbial strains used in this study. The results of the study are summarized in Table 4. Structural modification of the synthesized derivatives or synthesis of new derivatives might result more potent benzimidazole derivatives with significant antimicrobial activities.

In DPPH free radical scavenging assay notable antioxidant activity was not observed with any synthesized compounds. Compounds $\mathbf{1 a}$ and $\mathbf{1 b}$ showed mild antioxidant activity with $\mathrm{IC}_{50}$ values of $12.25 \times 10^{3} \mu \mathrm{g} / \mathrm{ml}$ and $87.326 \times 10^{3} \mu \mathrm{g} / \mathrm{ml}$ respectively. Other compounds showed negligible antioxidant activity (Table 5). The main reason behind this negligible antioxidant activity of the test samples is probably due to the absence of hydrogen atoms that can be released to act as a reducing agent.

\section{CONCLUSION}

Seven substituted benzimidazole derivatives have been synthesized smoothly by a simple method and screened for several pharmacological activities among which compounds 1c, $2 \mathbf{c}$ and $2 \mathbf{d}$ showed the most significant analgesic, anti-inflammatory and cytotoxic activities. Further studies and structural optimization of these compounds can lead to more potent, safe and effective drug molecules in future.

\section{CONFLICT OF INTEREST}

The authors state that they do not have any conflict of interest.

\section{CONTRIBUTION OF AUTHORS}

The design and intellectual supervision of the whole research was performed by SMAR. The synthesis and experiments with animals were carried out and analyzed by PS. The rest of the work, literature review and writing of the manuscript were completed by SRB and PS.

\section{ACKNOWLEDGEMENTS}

The authors appreciate Jahangirnagar University, Bangladesh for supplying the experimental animals and Institute of Food and Nutrition, University of Dhaka, Bangladesh for providing animal house facilities. The research was financially supported by National Science and Technology (NST) fellowship (39.00.0000.012.002.03.18-561[26]) and the first author is thankful to the Ministry of Science and Technology, Government of the People's Republic of Bangladesh for the fellowship.

\section{REFERENCES}

1. El Rashedy, A.A. and Aboul-Enein, H.Y. 2013. Benzimidazole derivatives as potential anticancer agents. Mini Rev. Med. Chem. 13, 399-407.

2. Barker, H.A., Smyth, R.D., Weissbach, H., Toohey. J.I.; Ladd, J,N. and Volcani, B.E. 1960. Isolation and properties of crystalline cobamide coenzymes containing benzimidazole or 5,6-dimethylbenzimidazole. J. Biol. Chem. 235, 480-488.

3. Moolten, M.S, Fishman, J.B., Chen, J.C. and Carlson, K.R. 1993. Etonitazene: an opioid selective for the mu receptor types. Life Sci. 52, 199-203.

4. Sato, M. and Yamaguchi, A. 1982. Studies on mechanisms of action of emorfazone. Effects on the release of bradykininlike substance in thermic edema of rat paws. 1982. Arzneimittel-forschung. 32, 379-382.

5. Bistrović, A., Krstulović, L., Stolić, I., Drenjančević, D., Talapko, J., Taylor, M. C., Kelly, J. M., Bajić, M. and RaićMalić, S. 2018. Synthesis, anti-bacterial and anti-protozoal activities of amidinobenzimidazole derivatives and their interactions with DNA and RNA. J. Enzyme Inhib. Med. Chem. 33, 1323-1334.

6. Jennifer, T., Pote, L., Wade, E., Blumberg, E., and Bloom, R. D. 2008. Maribavir: a novel antiviral agent with activity against cytomegalovirus. Ann. Pharmacother. 42, 1447-1457.

7. Torstensson, L., and Wessen, B. 1984. Interactions between the fungicide benomyl and soil microorganisms. Soil Biol. Biochem. 16, 445-452.

8. Horton, J. 2000. Albendazole: a review of anthelmintic efficacy and safety in humans. Parasitology. 121(S1), S113S132. 
9. Tahlan, S., Kumar, S. and Narasimhan, B. 2019. Pharmacological significance of heterocyclic $1 \mathrm{H}-$ benzimidazole scaffolds: a review. BMC Chem. 13, 101.

10. Matsumoto, S. and Yamazoe, Y. 2001. Involvement of multiple human cytochromes P450 in the liver microsomal metabolism of astemizole and a comparison with terfenadine. Br. J. Clin. Pharmacol. 51, 133-142.

11. Eerenberg, E. S., Kamphuisen, P. W., Sijpkens, M. K., Meijers, J. C., Buller, H. R. and Levi, M. 2011. Reversal of Rivaroxaban and Dabigatran by Prothrombin Complex Concentrate: A Randomized, Placebo-Controlled, Crossover Study in Healthy Subjects. Circulation. 124, 1573-1579.

12. Ogihara, T., Nakao, K., Fukui, T., Fukiyama, K., Ueshima, K., Oba, K., Sato, T. and Saruta, T. 2008. Effects of candesartan compared with amlodipine in hypertensive patients with high cardiovascular risks: candesartan antihypertensive survival evaluation in Japan trial. Hypertension. 51, 393-398.

13. Rabasseda, X. 2002. Ramosetron, a 5-HT3 receptor antagonist for the control of nausea and vomiting. Drugs Today (Barc). 38, 75-89.

14. Barot, K.P., Nikolova, S., Ivanov, I. and Ghate, M.D. 2013. Novel research strategies of benzimidazole derivatives: a review. Mini Rev. Med. Chem. 13, 1421-1447.

15. Steffen, R., Sack, D. A., Riopel, L., Jiang, Z., Stürchler, M., Ericsson, C. D., Lowe, B., Waiyaki, P., White, M. and DuPont, H. L. 2003. Therapy of travelers' diarrhea with rifaximin on various continents. Am. J. Gastroenterol. 98, 1073-1078.

16. Saha, P.; Brishty, S. R. and Rahman, S. M. A. 2020. Synthesis and evaluation of disubstituted benzimidazole derivatives as potential analgesic and antidiarrheal agents. Indian J. Pharm. Sci. 82, 222-229.

17. Brishty, S. R.; Saha, P.; Mahmud, Z. A. and Rahamn, S. M. A. 2020. Synthesis and evaluation of analgesic and antioxidant activities of substituted benzimidazole derivatives. Dhaka Univ. J. Pharm. Sci. 19, 37-46.

18. Poddar, S. K.; Saqueeb, N. and Rahman, S. M. A. 2016. Synthesis and Biological Evaluation of 2-methyl-1Hbenzimidazole and 1H-benzimidazol-2-yl-methanol. Dhaka Univ. J. Pharm. Sci. 15, 83-87.

19. Saha, A., Masud, M.A., Bachar, S.C., Kundu, J.K., Datta, B.K., Nahar, L. and Sarker, S.D. 2007. The analgesic and anti-inflammatory activities of the extracts of Phyllanthus reticulatus in Mice Model. Pharm. Biol. 45, 355-359.

20. D'Amour, F. E. and Smith, D. L. 1941. A method for determining loss of pain sensation. J. Pharmacol. Exp. Ther. 72, 74-79.

21. Hite, G. J.and Foye, W. O. 1981. Principles of Medicinal Chemistry. Philadelphia: Lea \& Febiger.
22. Kuźmierkiewicz, W., Foks, H., Hac, E. and Strzalkowskagrad, H. 1985. Synthesis and analgetic and antiinflammatory activity of derivatives of $3-(1 \mathrm{H}-$ benzimidazole-2) propanoic acid. Pharmazie. 40, 462-464.

23. Winter, C. A.; Risley, E. A. and Nuss, G. W. 1962. Carrageenin-induced edema in hind paw of the rat as an assay for anti-inflammatory drug. Proc. Soc. Exp. Biol. Med. 111, 544-550.

24. Owoyele, B. V., Oguntoye, S. O., Dare, K.; Ogunbiyi, B. A., Aruboula, E. A. and Soladoye, A. O. 2013. Analgesic, antiinflammatory and antipyretic activities from flavonoid fractions of Chromolaena odorata. J. Med. Plant Res. 2, 219225.

25. Meyer, B. N.; Ferrigni, N. R.; Putnam, J. E.; Jacobsen, L. B.; Nichols, D. E J. and McLaughlin, L. J. 1982. Brine shrimp: a convenient general bioassay for active plant constituents. Planta m Med. 45, 31-34.

26. Krishnaraju, A. V., Rao, T. V., Sundararaju, D., Vanisree, M., Tsay, H. S. and Subbaraju, G. V. 2005. Assessment of bioactivity of Indian medicinal plants using brine shrimp (Artemia salina) lethality assay. Int. J. Appl. Sci. Eng. 3, 12534.

27. Ruangpan, L. and Tendencia, E. A. 2004. Laboratory manual of standardized methods for antimicrobial sensitivity tests for bacteria isolated from aquaculture. In: Iloilo, Philippines: Southeast Asian Fisheries Development Center, Aquaculture Department, pp. 13-29.

28. Bauer, A. W., Kirby, W., Sherris, J. C. and Truck, M. 1966. Antibiotic susceptibility testing by a standardized single disc method. Am. J. Clin. Pathol. 45, 31-34.

29. Brand G. W. S. 1995. The free radical scavenging activities by DPPH. J. Uni. Med. 39, 18-21.

30. Hasan, P. and Williams, J. 2012. Basic opioid pharmacology: an update. Br. J. Pain. 6, 11-16.

31. Gaba, M.; Singh, S. and Mohan, C. 2014. Benzimidazole: An emerging scaffold for analgesic and antiinflammatory agents. Eur. J. Med. Chem. 76, 494-505.

32. Kavita, C. S., Kallappa, A., Hosamani, M. and Seetharamareddy, H. R. 2010. In-vivo analgesic and antiinflammatory activities of newly synthesized benzimidazole derivatives. Eur. J. Med. Chem. 45, 2048-2054.

33. Kamil, A.; Akhtar, S.; Karim, A.; Ahmed, A.; Wajdi, M.; Khan, Z. and Saify, S. 2013. Benzimidazole derivatives with potential cytotoxicity activity - synthesis and their structureactivity relationship. FUUAST J. Biol. 3, 87-93.

34. Kankate, R. S., Pagare, A. H., Pingale, R. S., Shaikh, A. R.; Kshirsagar, S. J., Chaudhari, D. and Patil. 2015. Design, synthesis, characterization and in-vitro evaluation of cytotoxic activity of novel copper complexes of sunstituted 1-H benzimidazole. Int. J. Pharm. Sci. Res. 6, 1307-1318. 